\title{
Evaluation and control of ergonomics actions in federal public service: the case of FIOCRUZ - RJ ${ }^{1}$
}

\author{
Simone L. Santa Isabel Ricart ${ }^{\mathrm{a},}$, Mario Cesar Rodriguez Vidal ${ }^{\mathrm{b}}$, Renato José Bonfatti ${ }^{\mathrm{c}}$ \\ ${ }^{a}$ Coordenação de Saúde do Trabalhador (CST), Diretoria de Recursos Humanos (DIREH), Fundação Oswaldo \\ Cruz (FIOCRUZ),RJ, Brasil e Grupo de Ergonomia e Novas Tecnologias (GENTE), Engenharia de \\ Produção/COPPE, Universidade Federal do Rio de Janeiro (UFRJ), RJ, Brasil. \\ ${ }^{\mathrm{b}}$ Grupo de Ergonomia e Novas Tecnologias (GENTE),Engenharia de Produção/COPPE, Universidade Federal \\ do Rio de Janeiro (UFRJ), RJ, Brasil. \\ ${ }^{c}$ Grupo Direitos Humanos e Saúde Helena Besserman (DIHS),Escola Nacional de Saúde Pública (ENSP), \\ Fundação Oswaldo Cruz (FIOCRUZ), RJ, Brasil
}

\begin{abstract}
This article presents information about the development of the dissertation. Deals with the production of ergonomic diagnosis in the environments and work processes of an important center of research and development in Public Health, Fiocruz. Critically evaluates the performance of a team promoting and facilitating the process of implementing ergonomic changes suggested. Through analysis of documents and statements by some managers and representatives of Human Resources was possible to identify the factors that facilitate and hinder the implementation process, linking them to the organization of the institution and conduct of the agents involved. Finally, it makes a reflection on practice, results and developments involved in the processes of change initiated by the ergonomic actions, proposing its replication along with other institutes of the Civilian Personnel of Federal Public Administration.
\end{abstract}

Keywords: Ergonomic actions, process implementation, SIASS

\section{Introduction}

Brazilian Ergonomics has been standing out in Latin America from the international diffusion of concepts. Methodological approaches have their origin in the Anglo-Saxon school and French school. The latter one, being proposed by Wisner, most commonly used in different studies.

There are many definitions that describe scientific ergonomics. The most used definition and internationally referenced is the one adopted by the International Ergonomics Association: "Ergonomics (or human factors) is the scientific discipline concerned with the understanding of the interactions among humans and other elements of a system, and the profession that applies theoretical principles, data and methods to design in order to optimize human well being and overall system performance." 1

Commonly found in the approaches of different authors, its focus on the labor situation, whose purpose is to seek changes in sys-productive to ensure its optimization, efficiency, productivity, comfort, health and safety of employees ${ }^{2}$.

The actions in Ergonomics, in Brazil, have been widely developed in private organizations with the main perspective of attend the regulatory requirements by the supervision of the Ministry of Labor. This demand, usually target the working condition adjustment to those who have employees covered by the Consolidation of Labor Laws. (CLT). The trajectories of labor regulation and social protection in the public sector were followed in a different way from those followed in the private sector. ${ }^{3}$.

*Corresponding author: Av. Brasil, 4365- Manguinhos. Pavilhão Carlos Augusto da Silva, sala 208. Rio de Janeiro - RJ. CEP: $21040-900$.

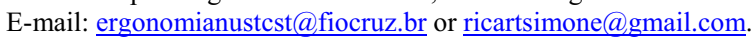


The lack of a national health policy of the federal public servant articulated by the State of Brazil's favored the emergence of health services with financial resources, physical structures and organizational and expert rules well differentiated. This differentiation had caused distortions in the concessions and benefits actions for the health of the public servant.

Thus, the actions in ergonomics, in some public organizations, arise from the strict needs, usually linked to resolving the issues of health and illness at work, within the context of workers' health.

The government had become also concerned with the growing number of cases of disability retirement. This growth, in the period between 2001 and 2005 cost about $\mathrm{R} \$ 2$ billion per year.

Despite some challenges to be faced by the Government, efforts are being applied to ensure the successful implementation of the Subsystem Integrated Health Care of the Federal Public Servant - SIASS. "The SIASS aims to coordinate and integrate activities and programs in the areas of promotion and health surveillance, disease prevention, expertise and official monitoring of the public servant's health of the Direct Federal Administration, local government and foundations, according to policy health care and safety of the federal public servant, established by the Government." 5

In order to define general guidelines for implementation of surveillance activities to the environments and work processes, and health promotion of civil public servant in Federal Agencies and institutes that make up the Civilian Personnel System of Federal Public Administration (SIPEC) was instituted Operational Norm of public servant Health (NOSS), through Ordinance No. 03 in Normative May, $07^{\text {th }}$ 2010.

The concepts of health promotion and monitoring of the public servants are lined on the health actions that aim to intervene in the disease process in their individual aspects and their collective relationships in the workplace through the transformation of work processes. This intervention should include a participatory and multidimensional attitudes to intervene on the determinants of health of the public servant on his work environment.

Therefore, the changes that were proposed in work processes and participatory approach included in the concept surveillance and health promotion, instituted by NOSS, converge to the principles and methods applied in ergonomics, in other words, to appreciate, to analyze and to propose preventive measures and corrective environments and work processes.
Henri Rouilleault in Guerrin ${ }^{6}$ gives emphasis that ergonomic actions needs to approach the systemic reality of the company complying with the observation and integration of the existing relations between the conditions in the work material, organizational, and the results of its activity.

Therefore, it is necessary that the expert professional ergonomics increase its appreciation for the connections of the microergonomics approach with a view of the work process. From this, the knowledge of ergonomics can be used in functional articulation of these two levels, the microergonomics and macroergonômics $^{7}$.

Hall Hendrick ${ }^{8}$ adds that interventions microergonômics not aligned and congruent to the aspects related to the macroergonomics, the results may not produce satisfactory effects linked to organizational improvement.

Despite its unquestionable importance, the relation among the organizational parameters, the type and intensity of preventive measures implemented by companies, ergonomics is still a line of research that has received comparatively little attention, as converged with Arocena et al. ${ }^{9}$

Encouraged by these thoughts and questions, this study aims to present the results of the last 10 years of ergonomic actions produced in a Federal Public Health Institute, Oswaldo Cruz Foundation - FIOCRUZ / RJ, whose actions are included in the context of Occupational Health; To identify the changes resulted from the ergonomic action, and to indicate facilities and difficulties encountered in implementing the proposed changes.

Initially, will be identified the history and the organizational structure of the Oswaldo Cruz Foundation as an institution of the Federal Public Health. Then, will be presented the concept and characteristics of workers' health and their function in FIOCRUZ. Finally, will be mentioned how the actions of ergonomics were introduced in the context of worker's health, describing the steps, methods and tools used by Team Ergonomics for the development of their actions.

\section{The Oswaldo Cruz Foundation - FIOCRUZ/RJ}

Situated on a campus of 800,000 square meters in the district of Manguinhos, North Zone of Rio de Janeiro, Fundação Oswaldo Cruz, adapted itself as a center for knowledge of the reality of the country and valorization of experimental medicine. Nowadays, 
under the Ministry of Health's, it's mission is to "generate, absorb and disseminate scientific and technological knowledge in health by the development of integrated research and technological development, education, production of goods, services, information and referral with the aim of providing strategic support to the Public Health System (SUS) and contribute to improving the quality of life and the totality of citizenship." 10

To fulfill its mission, the institution is made up of Direct Assistance Agencies to the Presidency, 14 Scientific and Technical Units, a Technical Support Unit and four Technical and Administrative Unit, forming the Executive Board. Among the 14 units, five are located outside of the Campus of Manguinhos, where four of these are in other states.

The institution has approximately 10,000 professionals working in several kinds of relations of employment with activities that include: the development of researture, the provision of hospital services and ambulatory health rials reference, the production of vaccines, drugs, reagents and kits diagnosis, education and training of human resources, the information and communication in health, science and technology, quality control of products and services, and implementation of social programs.

The multiplicity of existing work processes in the institution as a complex of health. This diversity sets up a scenario that requires an interdisciplinary approach, with features that are maintained in accordance with the procedures and working relationships already existing units ${ }^{11}$.

\subsection{The Occupational Health and FIOCRUZ}

Conceptually, it is understood by Occupational Health "a set of activities that is intended, through the actions of the epidemiological surveillance and health monitoring, promoting and protecting health workers, and seeks the recovery and rehabilitation of the health of workers subjected to risks and hazards arising from working conditions" 12 .

The field of occupational health differs from the Occupational Medicine and Occupational Health by the inclusion of the work process, employee participation and interdisciplinary action. It is considered a theoretical and methodological framework that seeks to get to know and intervene in labor relations and health and disease ${ }^{13}$. These skills have shaped the actions of health workers at FIOCRUZ.

In order to integrate the areas of assistance, health monitoring and prevention technique, and its interface with the working conditions in the 80 's, the Of- fice of Health Care Workers of FIOCRUZ (FIOSAST) was opened and linked to the Centre Occupational Health studies and Human Ecology (CESTEH) National School of Public Health (ENSP).

In 1996, the Coordination of Occupational Health (CST) was created as an executive authority of the President of FIOCRUZ, articulated the policy of human resources for improvements in health and safety of workers at FIOCRUZ, following the guidelines of the Institutional Program Healthy FIOCRUZ ${ }^{11}$. Currently, the CST has as its mission "To ensure the improvement of working conditions and health of workers at FIOCRUZ, by formulating policies and strategies and coordination of surveillance activities of environments and work processes, promotion and care health, in accordance with institutional policy." 14

To fulfill its mission, the CST has the Center for Occupational Health (nust), Center for Retirement Comprehensive Assessment (NAIA), Center for Health Situation Analysis (NASS), Center for the Humanization of Labor (NUHT) Center of attention Functional Health (NAFS) and management of quality, Biosafety and Environment (GQBAM).

\subsection{The Ergonomic Action in FIOCRUZ}

The actions of ergonomics at Fiocruz are inserted in the scope of the tasks of the Center for Occupational Health (nust) of CST since 2001, along with other health teams - nutrition, psychology, social work, pharmacy, medicine and nursing - with the order to evaluate the working conditions of professionals, regardless of the bond they have with the institution. In addition to proposing changes to minimize and / or eliminate the risk factors present in the development of activities.

The ergonomics of the team not only meets Fiocruz-mind issues related to health-disease process at work, but also responds to the commanders of the process of functional rehabilitation, acquisition of furniture, guidelines that support the design of architectural projects, and answer the questions of continuous improvement processes required for quality certification.

To do so, makes diagnoses and proposes ergonomic changes in work processes and environments based on the methodological assumptions of Ergonomic Work Analysis (EWA) proposed by the Francophone schools $^{15}$. In an attempt to meet the needs and specificities of the institution, the team developed, empirically, an ergonomic assessment tool - the EAMETA.

Currently the team holds three types of action Ergonomic: Ergonomic Assessment of Work - AET, 
Evaluation Ergonomic Workstation - AEPT and Monitoring. The development of ergonomic actions (AET and AEPT) follows the 06 methodological steps: Receipt of Demand, Evaluation Planning, Implementation of Technical Visit the site to be evaluated; Data Consolidation; Return and Validation, and Preparation and Delivery Report. Are documented in the report, listed, described and proposed suggestions for improvement of work situations found and evaluated during the visits. Set, therefore, at the end of the process of assessment and diagnosis of ergonomic action. However, from the point of view of those who receive it, the report can be an instrument to managerial actions.

\section{Methodology}

To obtain data and information of this research was a necessary approach to the subject matter allowing you to create knowledge from the present reality in the field. Thus the methodology used had two phases. The first, consisting of a documentary survey. At this stage it was verified the sum of shares held ergonomic, units and the covered sectors, the correlation of unity with the institutional hierarchy, the total number of workers involved, as well as the origin and nature of demand.

The second phase, field research consisted of two steps. In the first follow-up forms were applied to workers who participated in the ergonomic assessments. The second, had the realization of semistructured interviews with managers of services, sectors and departments and representatives of the human resources services (SRH's) of the units that participated in the actions following the ergonomic conversational method, proposed by Vidal $^{16}$.

The forms contained questions about: - The worker's participation in the development of action;

- Identifying changes in the workplace; - The process of implementing the suggested changes, and

- The need to continue to seek improvements.

The script of conversation was drawn up from information obtained in the application form and included the following subjects:

- The role of managers and representatives from $\mathrm{Hu}-$ man Resources Services of the units involved;
- The engagement levels of the organization; - Integration with other sectors, departments or units; - The available budget for the implementation process;

- The identification of outcomes and impacts produced by the action ergonomic;

- The process of continuity of action developed ergonomic.

Both instruments were chosen in order to capture the perceptions of the collective work through their experiences, opinions, feelings and meanings of the changes in their environment and work process.

To consolidate and process the information obtained during the study field, the comments from the forms and semi-structured interviews were grouped considering their significance and their recurrence, following the content analysis proposed by Bardin ${ }^{17}$.

Access to data and information obtained through desk research and field, allowed the construction of a base of quantitative and qualitative data.

\section{Results}

From the analysis of documents from the implementation of the actions of ergonomics at Fiocruz, it was found that 56 actions were performed in 15 units, including: a Vice-President, two bodies of direct assistance to the Presidency, a Technical Support Unit, three boards and Scientific-Technical eight units. In this universe, were awarded 47 workplaces and about 412 workers in the total Fiocruz.

The implementation of ergonomic actions occurred after a formal request to the Ergonomics Team, called demand. In these, could be identi-fied the departures of the request - the source of demand (Grafic 1) - and the reasons why the request was made - the nature of demand (Grafic - 2) 


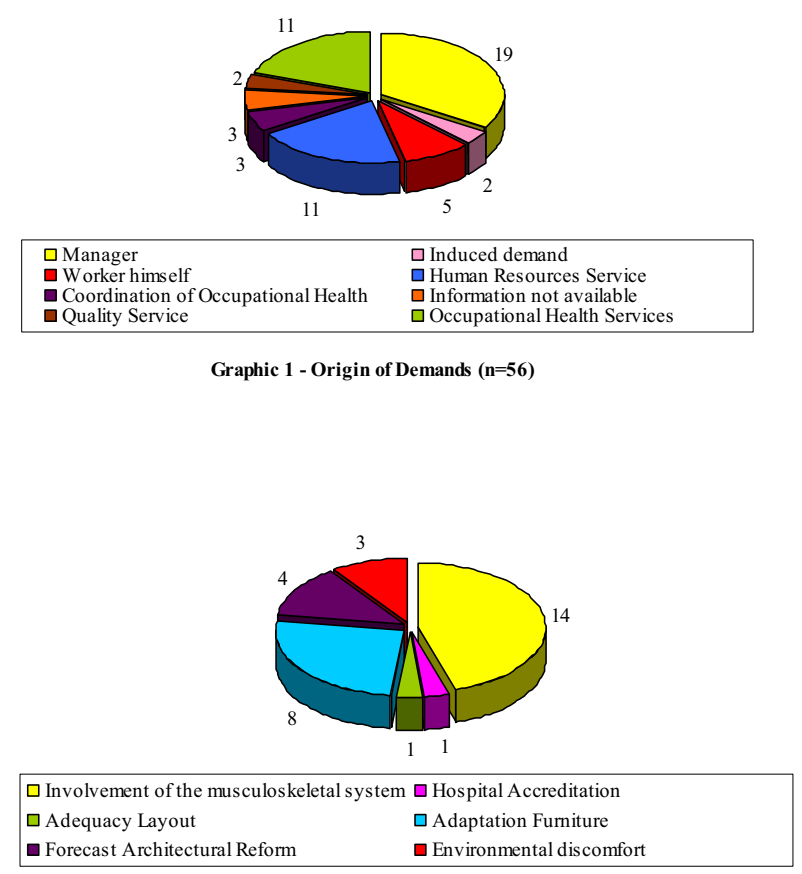

Grafic 2 - Nature of Demand ( $n=56$ )

In the implementing of the second methodology phase, from the 46 work enmviroments who have suffered ergonomic action, it was possible to establish contact with only 19 of 10 environments, 15 of the units covered. Therefore, 182 forms were sent to 19 work enmviroments in 10 units of Fiocruz. Of these, 112 forms from 16 work enmviroments retunred of those same 10 units.

In relation to the changes promoted in the workplace in the period after the ergonomic actions, it was found that 63 workers have been reported some level of transformation of positive characteristic. However a minority mentioned the lack of change in your workplace.

The changes reported were identified and grouped into categories: Space, Environment, Furniture, Equipment, Posture, Comfort, Organization Behavior and Safety (Table 1). These categories were established considering its relationship with the purpose of ergonomics and the recurrence of the identified items as proposed by Bardin 17 .
Table 1

\begin{tabular}{|l|l|}
\multicolumn{2}{|c|}{ Changes identified in the implementation process } \\
\hline \multicolumn{1}{|c|}{ Category } & \multicolumn{1}{c|}{ Comments } \\
\hline Space & $\begin{array}{l}\text { "With the changes I realized the importance of } \\
\text { having a larger space to work" (Q94 - Sector } \\
\text { XXIII) }\end{array}$ \\
\hline Environment & "All the lighting was changed" (Q13 - Sector II) \\
\hline Furniture & "adequacy of furnitures" (Q3 - Sector I) \\
\hline Equipment & $\begin{array}{l}\text { "Changes in the exhaust, filter boxes." (Q22, } \\
\text { Q27, 28, 29 - Sector IV) }\end{array}$ \\
\hline Posture & $\begin{array}{l}\text { "Some wrong postures adopted earlier, were } \\
\text { virtually extinct." (Q31 - Sector V) }\end{array}$ \\
\hline Comfort & $\begin{array}{l}\text { "Now the workstation is much more practical } \\
\text { and comfortable" (Q55 - Sector VII) }\end{array}$ \\
\hline Organization & "more organized environment" (Q87 - Sector X) \\
\hline Behavior & $\begin{array}{l}\text { "Changes in work habits of individual rooms } \\
\text { and" (Q26 - Section IV) }\end{array}$ \\
\hline Security & $\begin{array}{l}\text { "exchange of furniture making lower the risk of } \\
\text { accident" (Q87 - Sector X) }\end{array}$ \\
\hline
\end{tabular}

Regarding the process of implementing the changes suggested, 53 people had some kind of difficulty in that process. The difficulties reported during the implementation of the changes were grouped into categories: availability of appropriated funds, involvement of other sectors, involvement of managers, organizational behavior and time spent for execution of the transformation. (Table 2)

Table 2

\begin{tabular}{|l|l|}
\hline \multicolumn{2}{|c|}{ Difficulties encountered in the implementation process } \\
\hline Category & \multicolumn{1}{c|}{ Comments } \\
\hline Available budget & $\begin{array}{l}\text { "Lack of funding requested for the } \\
\text { purchase of furniture" (Q17 - } \\
\text { Sector III) }\end{array}$ \\
\hline Involving other sectors & $\begin{array}{l}\text { "Some claim relies on other units } \\
\text { or even money" (Q26 - Sector IV) }\end{array}$ \\
\hline Involvement of managers & $\begin{array}{l}\text { "(..) Lack of commitment by } \\
\text { managers "(Q109- Sector XV) }\end{array}$ \\
\hline Organizational Behavior & $\begin{array}{l}\text { "Resistance to change (...)" (Q74 - } \\
\text { Sector IX) }\end{array}$ \\
\hline $\begin{array}{l}\text { Time spent for execution of } \\
\text { the transformation }\end{array}$ & $\begin{array}{l}\text { "Authorization for implementation } \\
\text { of recommendations and delay on } \\
\text { the part of sectors to perform" } \\
\text { (Q22 - Sector IV) }\end{array}$ \\
\hline
\end{tabular}

It was also found that 80 people continue to seek improvements in its processes and work environments and 79 indicate the day of action to other sectors. These results may suggest a possible change in the behavior of people in the identification of the work that requires modification and ram-may indicate a good level of employee satisfaction with the implementation of the action.

Also in the second phase methodology, we interviewed 12 people, among which 08 are managers of the places where the action was ergonomic, and 4 are representatives of SRH's the units involved. The 
comments made during the action conversational were grouped from the content analysis proposed by Bardin ${ }^{17}$ agents that facilitated (Table 3) and agents that difficult (Table 4) the process of ergonomic intervention.

Table 3

\begin{tabular}{|c|c|}
\hline \multicolumn{2}{|c|}{ Agents in the Implementation Process Facilitators } \\
\hline Category & Comments \\
\hline $\begin{array}{l}\text { Implementation of simple and } \\
\text { inexpensive }\end{array}$ & $\begin{array}{l}\text { "(...) what you can do at home } \\
\text { and have to buy at low cost, } \\
\text { then the thing is easier to } \\
\text { implement. "(E6 - Manager } 3 \text { ) }\end{array}$ \\
\hline $\begin{array}{l}\text { Use of funds (budget) whose } \\
\text { origin comes from research } \\
\text { projects }\end{array}$ & $\begin{array}{l}\text { "(..) laboratories have extra } \\
\text { money just using the other } \\
\text { much more money because the } \\
\text { value of the extra money is } \\
\text { sometimes far greater than the } \\
\text { value that comes Treasury. "(E1 } \\
\text { - Representative SRH 1) }\end{array}$ \\
\hline $\begin{array}{l}\text { Support from immediate } \\
\text { managers of the evaluated } \\
\text { environments }\end{array}$ & $\begin{array}{l}\text { "(...) when I identified who had } \\
\text { a problem, requested that an } \\
\text { assessment, the HR head and } \\
\text { gave full support to it." (E2 - } 1 \\
\text { Manager) }\end{array}$ \\
\hline $\begin{array}{l}\text { Need to perform a pre- } \\
\text { planning teams }\end{array}$ & $\begin{array}{l}\text { "(...) all units are at the } \\
\text { beginning of a budget year ' } x \text { ' to } \\
\text { be spent (...) I think everything } \\
\text { is a matter of planning. "(E4 - } \\
\text { Representative SRH 3) }\end{array}$ \\
\hline $\begin{array}{l}\text { Integration with the team's } \\
\text { shopping service "we } \\
\text { managed to involve the } \\
\text { administration }\end{array}$ & $\begin{array}{l}\text { (...) sensitize staff of the } \\
\text { shopping area (...) if you can } \\
\text { fine-tune the dialogue and make } \\
\text { a good specification is not } \\
\text { guaranteed, but decreases much } \\
\text { risk you buy a bad thing. It's } \\
\text { just more work! "(E3 - } \\
\text { Representative SRH 2) }\end{array}$ \\
\hline
\end{tabular}

Table 4

Agents that have hampered the process of implementation Category $\quad$ Comments

"I got a lot (...). Only thing is, we depend on other units, or is no longer here. We depend on others to be charging, and then things are not that good. "(E2 Manager 1)

"I think the undeniably part of the public area that is the bureaucratic part of the public area, is one thing that really disturbs many decisions that are made" (E1 - Representative SRH 1 )

"Here in the public service we have this problem also, you have to buy what is cheaper, which appears in the quotation and sometimes, sometimes not, in most cases is of poorer quality. And then the cheap

Difficulties related to the procurement process

\begin{tabular}{|l|l|}
\hline & $\begin{array}{l}\text { also have this problem. "(E2 - } \\
\text { Manager 1) }\end{array}$ \\
\hline $\begin{array}{l}\text { Difficulty in establishing } \\
\text { information flow between } \\
\text { different hierarchical levels of } \\
\text { the constituent organization }\end{array}$ & $\begin{array}{l}\text { "for you or sensitize sensitize } \\
\text { the top one, it must be open and } \\
\text { that someone who knows what } \\
\text { is being spoken" (E11 - } \\
\text { Manager 7) }\end{array}$ \\
\hline & $\begin{array}{l}\text { (...) Once a person reached that } \\
\text { level of power that gives you } \\
\text { the position, it also creates a } \\
\text { comfort zone, and every time } \\
\text { you talk about changing } \\
\text { something to give, to grant the } \\
\text { other a little of that power , it } \\
\text { bothers (...) (E9 - Manager 5) }\end{array}$ \\
\hline
\end{tabular}

The use of the conversational method, through the script of conversation, allowed us to access information with a wider scope when compared to subjects initially proposed.

\section{Discussion and concluding remarks}

This research addressed the need to evaluate the results produced by the development of ergonomic actions at Oswaldo Cruz Foundation (FIOCRUZ) in a period of 10 years of existence. Aimed at knowing the reasons and the reasons for successes and failures in the processes of implementation of suggested improvements from the implementation of ergonomic action.

The methodology employed in research allowed uncovering some of the facilities, barriers and managerial and organizational constraints involved in the process of implementing the proposed changes by the action ergonomic.

It was found that the steps, methods and tools used by Team Ergonomics for the development of their actions became sufficient for the formulation of diagnoses and propose ergonomic improvements to work situations evaluated.

The results indicated that the report was used on a recurring basis as a management tool essential to polls suggested changes and was recognized as a technical instrument issued by a specialized team of Coordination of Occupational Health FIOCRUZ.

It was demonstrated also in agreement with Dul and Neumann ${ }^{18}$ and Hendrick ${ }^{19}$, the implementation of some recommendations made was made possible by the mobilization or personal initiative of managers taking on the responsibility to ensure the changes.

In analyzing the results and impacts produced by the action ergonomic became evident that even before the facilitating factors and constraints, the im- 
plementation of the changes achieved seem to be satisfactory.

The development of an ergonomic action inserted in the institutional context generates a series of developments by putting the team with the role of ergonomics is to advise, facilitate, promote, or warrant the intermediation of contacts and integration and coordination between the different teams, industries, services and units responsible for implementing the recommendations.

It points out that the actions developed in the scope of ergonomic public institutions are still incipient and require institutional maturity to ensure the development, implementation and monitoring of these initiatives. Thus, we propose the establishment of an Institutional Program of Ergonomics at Fiocruz. This proposal aims to address the magnitude, diversity and complexity involved in an institution like Fiocruz.

We believe that our establishing guidelines for implementation of the Surveillance and Health Promotion of the Federal Civil Servants, you can expose the actions ergonomic, with its participative approaches and multidisciplinary character also included in the concept surveillance and health promotion can be replicated and used as the instrument for the assessment and analysis of environments and work processes in the organs and entities of the Personnel Administration of the Civil Administration, as suggested in the SIASS.

Therefore, the development of this study can initiate a series of discussions on the development of actions of ergonomics within the federal public institutions. As well as promote a conscious movement of working people for better working conditions and guarantee you at a healthy, safe, efficient and sustainable.

\section{References}

[1] International Ergonomics Association. Site Oficial: http://www.iea.cc (Acessado em 17/02/2009)

[2] Mafra, J., Vidal, M. Inovação e Ergonomia: Novos Produtos, Novos Processos Ou Novos Paradigmas. Anais do Congresso Brasileiro de Ergonomia - ABERGO 2002 - Recife. Disponível em http://www.ergonomia.ufrj.br/artigos/02_\%204.pdf (Acessado em $02 / 05 / 09$ )

[3] Andrade, Elsa Thomé de., 2009. O Processo de Implementação da Política de Atenção à Saúde do Trabalhador em Instituições Públicas Federais: o desafio da integralidade. Dissertação de Mestrado apresentado na Escola Nacional de Saúde Pública Sérgio Arouca. Rio de Janeiro
[4] Boletim Eletrônico do Servidor: CONTATO. n51, 27 de outubro de 2005, do Ministério do Planejamento Orçamento e Gestão. http://www.planejamento.gov.br ou http://www.servidor.gov.br/publicacao/boletim_contato/bol_c ontato_05/arquivos_down/contato51_final.pdf (acessado em $16 / 05 / 2011)$

[5] BRASIL, Presidência da República - Casa Civil., 2009, Decreto $n^{\circ} 6833$ de 29/04/2009. Brasília. Publicada no D.O.U em 30/04/2009. Disponível em http://www.planalto.gov.br/ccivil_03/_Ato20072010/2009/Decreto/D6833.htm Acessado em 12/08/2010

[6] Guérrin, F. et al. (2001) Compreender o Trabalho para transformá-lo: a prática da ergonomia. São Paulo: Blücher: Fundação Vanzolini

[7] Amell, T.K., Kumar, S., Rosser, B.W.J., 2001, "Ergonomics, loss management, and occupational injury and illness surveillance. Part 1: elements of loss management and surveillance. A review". International Journal of Industrial Ergonomics 28 (69-84) - Elsevier Science

[8] Hendrick, Hal W., 2006, Macroergonomia: uma introdução aos projetos de sistemas de trabalho. - Rio de Janeiro: Virtual Cientìfica

[9] Arocena, P., Nnunez, I., Villanueva, M., 2008, "The impact of prevention measures and organisation factors on occupational injuries". Safety Science 46 (1369-1384) - Elsevier Science

[10]Plano Quadrienal, Fiocruz - Out, 2005 extraído do Site Oficial da Fundação Oswaldo Cruz - FIOCRUZ. http://www.fiocuz.br (acessado em 11/11/2010)

[11]Minayo, M. C. S., et al., 1998, "Fiocruz Saudável - uma experiência institucional". Ciência e Saúde Coletiva, 3(2)

[12]BRASIL., 1990, Lei Orgânica da Saúde $n^{\circ} 8080$ de 19/09/1990. Publicado no D.O.U. em 20/09/1990. Brasília. Disponível http://www.planalto.gov.br/ccivil 03/Leis/L8080.htm Acessado em 06/09/2010

[13]Lacaz, F.A.C., 2007, "O Campo Saúde do Trabalhador: resgatando conhecimenntos e práticas sobre as relações trabalho-saúde". Caderno de Saúde Pública. Rio de Janeiro, 23(4): 757-766

[14] Site Oficial da Fundação Oswaldo Cruz - FIOCRUZ. http://www.fiocuz.br (acessado em 20/02/2010)

[15] WISNER, Alain. (1987) Por dentro do trabalho. Ergonomia: método e técnica. São Paulo: FTD: Oboré

[16]Vidal, M. C., 2003, Guia para Análise Ergonômica do Trabalho (AET) na empresa: uma metodologia realista, ordenada e sistematizada. Rio de Janeiro: Editora Virtual Científica

[17]Bardin, Laurence., 1979, Análise de Conteúdo.. Lisboa Edições 70. Edição Revista e Actualizada

[18] Dul, J. e Neumann, W.P., 2009 "Ergonomics contributions to company strategies". Applied Ergonomics 40 (745-752 ) Elsevier Science

[19]Hendrick, Hal W., 1996, Good Ergonomics is Good Economics - Proceedings of the Human Factors and Ergonomics Society 40th Annual Meeting. Human Factors and Ergonomics Society 